\title{
Türkiye'de Yerel Yönetimlerin Kentsel Açık-Yeşil Alan Yönetimi Stratejilerinin Değerlendirilmesi
}

DOI: $10.26466 /$ opus. 906382

*

\author{
Venhar Melda Hassamancioğlu* \\ * Arş.Gör., Tokat Gaziosmanpaşa Üniversitesi, Güzel Sanatlar Fakültesi, Tokat/Türkiye \\ E-Posta: melda.hassamancioglu@gop.edu.tr \\ ORCID: $\underline{0000-0003-3072-0749}$
}

\section{Öz}

Türkiye'de yerel yönetimlerin kentsel peyzaj yönetimi stratejilerinde peyzaja ilişkin yasal hükümlerin yetersiz olmasindan ve ulusal peyzaj politikası stratejilerinin oluşturulmamasından kaynaklanan sorunlar görülmektedir. Ulusal şehircilik politikalarında peyzajla ilgili stratejilerin bulunmasına ră̆men, peyzajın korunması, planlanması ve yönetimine ilişkin faaliyetlerin detaylandırilmaması, bu stratejilerin yerel politikalara yansımasını zorlaştırmaktadır. Ulusal ve yerel politikalarda peyzaj politikası kavramına yer verilmediğinden, çalışmada kentsel peyzajın nasıl yönetildiğini incelemek maksadıyla belediyelerde kentsel açık-yeşil alanların yönetim stratejileri değerlendirilmiştir. Bu amaçla, Türkiye'deki 30 büyükşehir belediyesi örneklem olarak seçilmiş, belediyelerin kurumsal politika belgesi niteliğindeki 5 yıllık stratejik planlar materyal olarak kullanulmıştır. Belediyelerin, şehircilik, çevre ve sosyal politikalarının bir unsuru olarak değerlendirilen açık-yeşil alanlarla ilgili politikalarnna dair stratejik planlarda bulunan veriler derlenmiş, yerel yönetimlerde kentsel gelişim stratejileri ile uyumlu, bütüncül, bağlantılı̆̆ı bir yeşil alan sistemine yönelik stratejilerin varlığı sorgulanmıştır. Değerlendirmede, kurumsal raporlarda yeşil alanların nitelikleri ve işlevsellikleriyle değil yüzölçümleriyle ilgili bilgilere yer verildiği, planlardaki stratejilerin kentteki yeşil alan miktarın artırmaya yönelik faaliyetleri içerdiği gözlemlenmiştir. Bu faaliyetler; plan döneminde yapılacak olan rekreasyon alanlarl, bitkilendirme çalışmaları ve yeşil alanların bakım-onarım faaliyetleriyle sınırlı kalmıştır. Yerel yönetimlerin açı-yeşil alanların yalnızca rekreasyonel ve estetik işlevlerine odaklandı̆̆̆, diğer işlevlerini göz ardı ettikleri görülmüştür. Planların birçoğunda açı-yeşil alan planlaması ve sistematik şekilde yönetimine dair verilerin bulunmaması yerel peyzaj politikalarının oluşturulmadı̆̆ının göstergesidir.

Anahtar Kelimeler: Kentsel açık-yeşil alanlar, peyzaj politikası, yerel yönetimler. 


\title{
An Evaluation of Urban Green Space Management Strategies of Local Governments in Turkey
}

\begin{abstract}
In Turkey, problems arising from insufficient legal provisions about landscape and not determining landscape policy strategies, are observed in the urban landscape management strategies of local governments. Although there are associated strategies with landscape in national urbanism policies, the lack of detailed actions related to landscape protection, planning and management makes complicated to reflect these strategies on local policies. Since the concept of landscape policy is not included in national and local policies, in this study, the management strategies about urban open-green areas in local governance have been evaluated in order to examine how the urban landscape is managed. For this purpose, 30 metropolitan municipalities in Turkey selected as the sample group, the 5-year strategic plans of the municipalities, which are the institutional policy documents, were used as material. The data in the strategic plans regarding the policies of the municipalities related to open-green areas, which are considered as an element of urbanism, environmental and social policies, were compiled. And the existence of strategies for a holistic, correlate green space system compatible with urban development strategies in local governments was sought. The assessment results show that corporate reports included information about the surface of green area, not the qualities and functionality of green spaces and the strategies in the plans contain actions to increase the amount of green space in cities. These actions were limited to recreation areas, planting works and maintenance services of green spaces that will be implemented in the plan period. It has been observed that local governments focus only on the recreational and aesthetic functions of open-green spaces and disregard their other functions. The absence of data on open-green space planning and systematic management in most of the strategic plans is an indication that local landscape policies are not established.
\end{abstract}

Keywords: Urban open-green spaces, landscape policy, local governments 


\section{Giriş}

Kent bileşenlerinin temel ve en önemli unsurlarından biri olan yeşil alanlar, kent karakterinin oluşumuna etkili ve kentteki yaşam kalitesine oldukça olumlu katkılar sağlayan alanlardır. Yeşil alanlar üstlendikleri ekolojik, ekonomik, fiziksel, toplumsal, psikolojik ve estetik işlevlerle kent yaşamının göz ardı edilemez birer parçasıdırlar (Öztürk, 2004). Bu nedenle yerel yönetimlerin yeşil alanlara ilişkin koruma, planlama ve yönetim stratejileri yerel yönetimler için önem arz etmekte ve bu stratejilerin iyileştirilmesi kentlerin gelişiminde önemli rol oynamaktadır. Fakat Türkiye'deki şehirlerde sistematik bir yeşil alan planlaması ve yönetiminin olmadığ1 görülmektedir. Çalışmanın amacı; Türkiye'deki büyükşehirlerin yerel yönetimlerinin peyzaj politikalarını değerlendirerek, açık-yeşil alanlara dair yönetim stratejilerini ortaya koymak, yeşil alanların dahil edildiği hizmet ve faaliyet alanlarını incelemek ve yerel yönetimlerde bütüncül bir yeşil alan yönetim sisteminin varlığını sorgulamaktır.

\section{Açık-Yeşil Alanların Tanımlanması ve Kentlerdeki İşlevleri}

Çalışma konusu olan açık-yeşil alan kavramın tasviri incelendiğinde açık alan ve yeşil alan kavramının ayrı ayrı tanımlandığı görülmektedir. Yeşil alanlar "Kent mekânı içinde fiziksel ve sosyal çevrenin niteliğini belirleyen, eğitimsel, kültürel ve rekreasyon amaçlı kullanımlara olanak tanıyan ve toplumun tüm bireylerinin kullanımına açık olan kamusal mekânlar" (Yuen, 1996; Ceylan, 2007) olarak tanımlanırken, açık alanlar ise "Mimari yapı ve ulaşım alanları dışında kalan açıklıklar veya boş alanlar"(Gül ve Küçük, 2001) olarak tanımlanmaktadır. Bu tanımların yasal çerçevedeki karşılığı ilgili yönetmelik olan 30113 sayılı Planlı Alanlar İmar Yönetmeliği'nde yer almaktadır. Yönetmelikte yeşil alan kavramı "Toplumun yararlanması için ayrılan oyun bahçesi, çocuk bahçesi, dinlenme, gezinti, piknik, eğlence, rekreasyon ve rekreaktif alanları toplamını (Metropol ölçekteki fuar, botanik ve hayvan bahçeleri ile bölgesel parklar bu alanlar kapsamındadır)" ifadesiyle tanımlanmışlardır.

Kent ve kent yaşamına sağladığı katkılar dikkate alındığında yeşil alanların 4 farklı grupta değerlendirilebilecek işlevleri vardır. Bunlardan ilki, enerji tasarrufu, turizm ve istihdam, mülk değeri ve üretimi artıran 
ekonomik işlevlerdir. Oksijen üretimi, kirli havanın temizlenmesi, mikro klimanın düzenlenmesi, nispi nem düzenlemesi, karbon tutma ve sera gazı azalımı, erozyon önleme ve su dengesini sağlama, ekolojik restorasyon ve biyolojik çeşitliliğin korunması ve gürültünün azaltılmasını sağlayacak işlevleri ise ekolojik işlevler olarak değerlendirilmektedir. Toplumun sosyal gereksinimleri perspektifinden bakıldığında ise yeşil alanlar kentlerde; kültürel ve rekreasyonel faaliyetlere olanak oluşturma, kamu sağlığını koruma, toplumsal gelişmeye katkı sağlama ve suç oranını azaltma gibi işlevlere sahiptirler. Planlama yönünden fiziksel işlevleri ise, dolaşım-erişim, alan koruma, tarihi koruma, estetik, mimari etki ve kentsel kullanımlar arasında tampon görevi görme ile ölçü yönünde denge sağlama maddeleriyle gruplandırılabilir (Önder ve Polat, 2012).

Kentsel açı-yeşil alanlar, kentlerdeki ekolojik ve sosyal sistemlerin birer parçası oldukları için ekosistem servisleri üretir ve kentsel dayanıkl1lığ1 artırırlar (Bolund ve Hunhammar 1999; Colding 2012). Ekosistem servisleri; "insan hayatının sürdürülebilmesi ve insan refahının sağlanabilmesi için ekosistemlerin sunduğu durumlar, süreçler, işlevler, faydalar ve ürünlerin tümü" (Albayrak, 2012) olarak tanımlanmıştır. Yeşil alanların bahsi geçen işlevleri ele alındığında doğal ve kültürel bağlamda birçok ekosistem servisini kent yaşamına sunduğu görülmektedir. Ekosistem servisleri, özellikle peyzaj planlama ve doğal kaynakların yönetiminde politika oluşturma ve karar alma süreçlerinde kapsayıcı bir çerçeve olan önemli bir araç haline gelmiştir (Tonyaloğlu ve Atak, 2020). Fakat, ekosistem servislerinin verimliliğini en üst düzeye çıkarmayı amaçlayan faaliyetlerde; mali kaynakların ve insan kaynaklarının kısıtlı olduğu durumlar ve ekolojik kaynakları yönetmenin sosyal ve politik karmaşıklığı göz önüne alındığında, bütüncül ve bağlantılı sosyal-ekolojik sistemlerin yönetilmesinde birçok zorlukla karşılaşıldığ1 görülmektedir (Wang vd, 2014).

Yeşil alanların kent yaşamına olumlu etki eden işlevleri ve sağladıkları ekosistem servisleri dikkate alındığında, her bir kent için ayrı yeşil alan stratejileri oluşturulması ve stratejilerin kentlerin mekânsal planlarına entegre edilmesinin yerel yönetimlerin görevleri arasında yer alması gerektiği görülmektedir. Oluşturulacak stratejiler kentlerdeki yeşil alan varlığ 1 ve dağılımı, erişilebilirlik, bütüncül yeşil alan sistemi ve bölge, kent, semt 
ve mahalle ölçeklerinde yeşil alan kademelenmesine yönelik formüle edilmelidir. Bu stratejiler kentlerin doğal ve ekolojik yapısına, sosyokültürel yapısına ve kent karakteriyle kimliğine uygun olmalı, kent planlarıyla makro ölçekten mikro ölçeğe uyumlu ve bütünsel planlama kriterleriyle oluşturulmalıdır (Manavoğlu ve Ortaçeşme, 2013).

\section{Türkiye'de Peyzaj Politikaları ve Kentsel Açık-Yeşil Alanlara İlişkin Politikalar}

Kentsel açık-yeşil alanları etkileyen politikaları değerlendirmek için uluslararası ve ulusal düzeyde peyzaj politikalarının incelenmesi gereklidir. Türkiye'de henüz yasal çerçevesi tam olarak netleştirilmemiş olan peyzaj politikası Avrupa Peyzaj Sözleşmesi'nde (2000) “Yetkili kamu makamları tarafından peyzajların korunması, yönetimi ve planlanması amacına yönelik olarak özel önlemlerin alınmasına izin veren genel ilkelerin, stratejilerin ve rehber kuralların ifadesi" olarak tanımlanmıştır. Uluslararası düzeyde peyzajı özel olarak ele alan ve kültürel ve doğal peyzajın korunmasını, yönetilmesini ve planlanmasını Avrupa genelinde sağlamayı hedefleyen Avrupa Peyzaj Sözleşmesi, 2000 yılında Avrupa birliğine üye ve aday ülkeler tarafından imzalanmıştır. 2003 yılında 4881 sayılı kanunla Türkiye'de de yürürlüğe giren sözleşme, Avrupa Birliğine uyum sürecinde önemli bir kriter oluşturmuştur. Fakat geçen süre boyunca sözleşmenin gereklilikleri tam olarak yerine getirilmemiş, iç hukukun bir parçası haline gelen sözleşme ile yapılan uygulamalar arasında uyumsuzluklar gözlemlenmiştir (Erdem ve Çoşkun, 2009). Türkiye'de peyzajı oluşturan bileşenlerin tasvir edildiği tanımlamaların yasal mevzuatta yer almaması ve peyzajın korunması, planlanması yönetimi, peyzaj kalite hedefi ve peyzaj politikası kavramlarına ilişkin kriterlerin yasal dayanaklarının belirlenmemiş olması nedeniyle, sözleşmenin uygulanmasında aksaklıklar yaşanmaktadır (Kaska, 2012). Ülkelerin kendi peyzaj politikalarını oluşturmasını, sahip oldukları peyzajları tanımlayarak onları değiştiren güç ve baskıları analiz etmesini ve bu değişimlerin de kaydedilmesini öneren Avrupa peyzaj sözleşmesi, Türkiye' de ulusal peyzaj politikası oluşturmak ve bu politikanın oluşmasını sağlayacak rasyonel politika araçlarını şekillendirmek için temel bir kaynak niteliğini taşımaktadır (Erdönmez, 2004). 
Ulusal politikaların belirlenmesine esas olan kalkınma planlarında ise peyzaja ilişkin amaç ve hedeflere yeterli düzeyde yer verilmemektedir. 10. Kalkınma Planı'nın 'Kültür ve sanat' başlığında yer alan 303.maddesi "Kent mimarisi ve peyzajının insan üzerindeki etkisi göz önünde bulundurularak, bu alanda yapılan çalışmaların kentin dokusuna, estetiğine ve kimliğine katkı sağlamasına özen gösterilecek; ayrıca kentsel dönüşüm çalışmalarının kültürel kimlik ve yapıya uygunluğuna dikkat edilecektir" (T.C. Kalkınma Bakanlığı, 2013) ibaresiyle kentleşme politikalarında peyzajın da dikkate alınmasın gerektiğini ifade etmiştir (Tunçer, 2015). Cumhurbaşkanlığ ${ }_{1}$ Strateji ve Bütçe Başkanlığ 1 tarafından hazırlanan 11. Kalkınma Planı'nın (2019) peyzaj ifadesini içeren tek maddesi 632 sayılı "Kentsel tasarımların, imar planlarının, toplu konutlar ve kamu binalar1nın peyzaja, şehrin dokusuna, estetiğine ve kimliğine katkı sağlamasına özen gösterilecek ve kentsel dönüşüm uygulamalarının kültürel kimliğe ve yapıya uygunluğu gözetilecektir." ifadesiyle önceki dönemde olduğu gibi nitelikli insan ve güçlü toplum oluşturma hedeflerinin kültür ve sanat başlığında yer almaktadır.

Yönetimsel açıdan bakıldığında peyzaj, diğer sektörlerin planlanmış politikalarının bir parçası olarak değerlendirilmektedir. Peyzaj unsurları Türkiye'de çevre politikaları, tarım politikaları, enerji politikaları ve şehircilik politikalarının içerisinde bir alt başlık olarak yer almaktadırlar. Peyzaj politikası kavramının henüz şekillenmemiş olmasına rağmen peyzaj, yetkili kamu kurum ve kuruluşlarının politika belgelerinde bahsi geçen diğer sektörlerle ilişkilendirilerek yer almaktadır.

Uluslararası ölçekte, yeşil alan planlamasına ilişkin kentsel politikaların belirlenmesinde ise yine Avrupa Konseyi tarafından düzenlenen Yerel ve Bölgesel Yönetimler Kongresi'nin çıtısı olan Avrupa Kentsel Şartı'nda (1992) kentlerde sürdürülebilir gelişim hedeflerine ulaşmak ve sağlıklı mekânlar yaratarak yaşam kalitesini artırmak için yeşil alan planlama stratejilerinin geliştirilmesi ve bu stratejilerin kentlerin mekânsal planlama ilkelerine entegre edilmesi gerekliliği vurgulanmıştır. Şartın 2008 y1lında güncellenen versiyonu olan Avrupa Kentsel Şartı 2'de son 50 yılda kentsel planlama çalışmalarında kent peyzajının mimari kalite göz ardı edilerek ihmal edildiği belirtilmiş, kentlerde canlı bir mimari kültürün gelişmesi hedeflenmiştir. Kentsel politika ilkelerini 2019 yılında imzalanan 
'Avrupa Yeşil Sözleşmesi' ile detaylandıran Avrupa Konseyi tarafından, Avrupa kentsel şartının kabulünden bu yana, yaşanan çevre ve iklim krizlerini önlemeye ve her bir canlıya sağlıklı bir çevrede yaşama hakkı sunmaya yönelik stratejiler geliştirilmiştir (Tuğaç, 2020).

Ulusal politika belgelerinde, 11. Kalkınma Planı'nda (2019) yeşil alanlara ilişkin hedefler 'şehirleşme' başlı̆̆ında yer almaktadır. Planın 675. Maddesinde yer alan "Başta açık ve yeşil alanlar olmak üzere şehirlerdeki kamusal alanların korunması; erişim ve güvenliğinin artırılması, kadınlara, çocuklara, yaşlılara, engellilere duyarlı olarak insan tabiat ilişkisi çerçevesinde yeniden kurgulanması sağlanacaktır" ifadesiyle yeşil alanların toplumun ihtiyaçlarına istinaden erişilebilirlik ve güvenlik açısından geliştirilerek sosyal politikalara dahil edilmesi gerekliliğini vurgulamıştır. 11. Kalkınma Planı'nın 676. Maddesi ise "Yeşil şehir vizyonu kapsamında yaşam kalitesinin artırılması ve iklim değişikliğine uyumu teminen şehirlerimizde Millet Bahçeleri yapılacak ve yeşil alanların miktarı artırılacaktır." (2019) ifadesiyle, yeşil alanların ekolojik işlevlerinin iklim değişikliğine uyum çalışmalarında aktif olmasını hedeflemektedir. Yeşil alanlara ilişkin uygulamaların yürütücülüğü plandaki 676.1. maddesi ile Çevre ve Şehircilik Bakanlığı, TOKI, İLBANK ve belediyelere bırakılmıştır.

Kent ve çevre politikalarının oluşturulması ve uygulanmasında yetki ve sorumluluk 1153 sayılı Çevre ve Şehircilik Bakanlığının Teşkilat ve Görevleri Hakkında Kanun Hükmünde Kararname (2011) ile bahsi geçen bakanlığa verilmiştir. Kararnamede görev tanımı; "prensip ve politikalar tespit etmek, standart ve ölçütler geliştirmek, programlar hazırlamak; eğitim, araştırma, projelendirme, eylem planları haritalar oluşturmak ve bunların uygulama esaslarını tespit etmek ve izlemek, iklim değişikliği ile ilgili iş ve işlemleri yürütmek" olarak belirlenen Çevre ve Şehircilik Bakanlı̆̆1 yönetim hiyerarşisindeki en üst kuruluştur.

Çevre ve Şehircilik Bakanlığı, kentsel gelişim stratejileri ve çevre yönetimi için eylem planları hazırlamakta ve kamuoyuna sunmaktadır. Hazırlanan 'Bütünleşik kentsel gelişme stratejisi veEeylem planı (KENTGES)'de kentsel gelişim stratejileri; "mekânsal planlama sisteminin yeniden yapılandırılması, yerleşmelerin mekân ve yaşam kalitesinin artırılması, yerleşmelerin ekonomik ve toplumsal yapılarının güçlendirilmesi" (2009) başlıklarıyla gruplandırılmışlardır. KENTGES'in yeşil alanlara ilişkin 8 numaralı hedefi "Mekânsal planlarda açık ve yeşil alanları sistem bütünlüğü 
içinde geliştirmek" olarak belirlenmiştir. Plandaki 8.1.2 numaralı eylem "Yerleşmelerdeki mevcut yeşil alanları koruyan ve mekânsal planlarda açık ve yeşil alanlar sistemini öneren düzenlemeler yapılacaktır" (2009) maddesini içermekte ve bu konuda ilgili kuruluş olarak Çevre ve Şehircilik Bakanlığı, belediyeler, il özel idareleri ve sivil toplum kuruluşlarını yetkilendirmektedir. Aynı bakanlık tarafından hazırlanan 'İklim Değişikliği Eylem Planı 2011-2023” de ise O.3.5.1 numaralı eylemi “kentsel tasarım ve peyzaj planlamada ekolojik yaklaşımları ve geri dönüşümü dikkate alan projelere destek verilmesi yoluyla karbon stokunun artırılması" (2012) hedefini içermektedir. Bakanlığın Mekânsal Planlama Genel Müdürlüğ̈̈'nün yayınladığı Kentsel Tasarım Rehberi (2016) adlı kılavuzlarda kentsel tasarım bütünleşik planlama sisteminin bir aracı olarak adlandırılmış ve kent peyzajı ile entegre tasarım çalışmalarını yürütmenin önemi, uluslararası örneklerdeki yönetim stratejilerinin açıklamaları ile vurgulanmıştır. Ayrıca, bakanlığın 'Mekânsal Stratejik Planı' hazırlıkları ise halen devam etmektedir.

\section{Yöntem}

Kentlerde açık-yeşil alanların yönetimi 5393 sayılı Belediye Kanunu gereğince belediyelerin yetki ve sorumluluğundadır. Bu çalışmada ulusal peyzaj politikalarının yerel yönetimlere yansımaları ve yerel yönetimlerin belirlenen politikalar doğrultusundaki açık-yeşil alan yönetimi stratejileri değerlendirilecektir. Araştırmada, nitel bir veri analizi yöntemi olan doküman analizi yöntemi kullanılmıştır. Doküman analizi süreci; araştırma konusunun seçiminden sonra dokümana ulaşılması, dokümanın sınırlandırılması, dokümanın orijinalliğini teyit edilmesi, dokümanın detaylı okunması ve ardından içerik analizinin yapılarak elde edilen verilerin değerlendirilmesi aşamalarından oluşmaktadır. (Kıral, 2000). Araştırmada örneklem olarak belirlenen kurumların dokümanları materyal olarak seçilmiş, içerik analizi için kategoriler oluşturulmuş ve dokümanlardaki veriler bu kategorilere göre değerlendirilmiştir. 


\section{Örneklem}

Araştırmada Türkiye'de bulunan 30 büyükşehir belediyesi örneklem olarak seçilmiş, Adana, Ankara, Antalya, Aydın, Balıkesir, Bursa, Denizli, Diyarbakır, Erzurum, Eskişehir, Gaziantep, Hatay, İstanbul, İzmir, Kahramanmaraş, Kayseri, Kocaeli, Konya, Malatya, Manisa, Mardin, Mersin, Muğla, Ordu, Sakarya, Samsun, Şanlıurfa, Tekirdağ, Trabzon ve Van illerinin büyükşehir belediyelerinin yeşil alanlara ilişkin politikalarını incelemek hedeflenmiştir. Şekil 1. Büyükşehir belediyesi statüsünde yerel yönetime sahip illerin haritasını içermektedir.

Büyükşehir belediyelerinin çalışma alanı olarak seçilme nedeni 2012 yılında 6360 sayılı kanunda yapılan değişiklikle oluşturulan yeni büyükşehir belediyesi yönetimi modeliyle, 13 il belediyesinin daha büyükşehir belediyesi statüsüne getirilmiş olması ve büyükşehir belediyelerinin mülki sınırları ilin coğrafi sınırları olarak değiştirilmesidir.

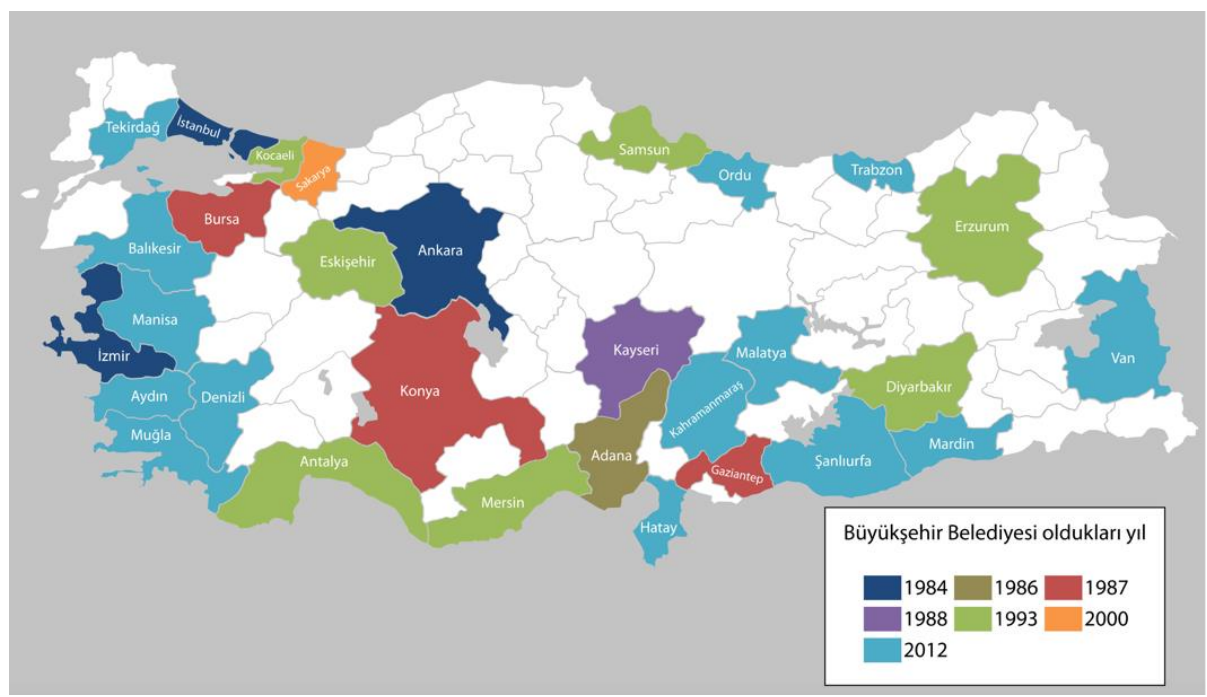

Şekil.1 Türkiye'de Büyüksşehir Belediyeleri (Anonim, 2019)

Büyükşehir belediyesi yönetimindeki 30 şehirde İl Özel İdareleri kald1rılarak yerel politikaların uygulanmasında il genelinde yetkili kurum olarak büyükşehir belediyeleri belirlenmiştir. Bu durumun yerel yönetimle- 
rin yetki alanlarını genişlettiği konusunda tartışmalar yaşansa da yeni düzenlemenin 'merkeziyetçi yerel yönetim' olarak tanımlandığı söylenmektedir (Arıkboğa, 2013). Yetki sınırlarının il sınırları olarak değiştirilmesiyle birlikte, il genelinde peyzajın korunması planlanması ve yönetimine dair tüm politika ve faaliyetleri uygulayan ve denetleyen kurumlar büyükşehir belediyeleri olmuşlardır. Bu nedenle, çalışma alanı olarak seçilen büyükşehir belediyelerinin politikalarında yeşil alanların yeri incelenmiştir. Peyzaj politikası kavramı yönetim birimlerince henüz yaygın olarak kullanılmadığından kurumların şehircilik politikaları, çevre politikaları ve sosyal politikaları çalışmada değerlendirilmiştir.

\section{Materyal}

İncelemede büyükşehir belediyelerinin 2003 yılında yürürlüğe giren 5018 sayılı Kamu Mali Yönetimi ve Kontrol Kanunu ile, kamu kurumları için planlaması zorunlu olan 5 yıllık stratejik planlarındaki politikaları ele alınmıştır. 5018 sayılı kanunla stratejik planlar "kamu idarelerinin orta ve uzun vadeli amaçlarını, temel ilke ve politikalarını, hedef ve önceliklerini, performans ölçütlerini, bunlara ulaşmak için izlenecek yöntemler ile kaynak dağılımlarını içeren plan" olarak tanımlanmışlardır. Stratejik planlar yerel yönetim politikalarının oluşum ve uygulanma süreçlerini içeren resmi birer politika belgesi olduğundan, belediyelerin politika ve faaliyetlerini değerlendirmek için planlardaki veriler ele alınmıştır. Araştırmada analiz edilen dokümanlar mevcut 30 büyükşehir belediyesinin araştırmanın yapıldığı 2021 yılında yürürlükte olan, 2020-2024 dönemi için hazırlanmış stratejik planlarıdır. Değerlendirme yalnızca stratejik planlarla kamuoyuna sunulan verilerle sınırlandırılmış, planlarda yer alan amaç ve hedeflerin gerçekleştirilme durumu ve planlara işlenmemiş yerel yönetim faaliyetleri değerlendirmeye dahil edilmemiştir.

\section{Verilerin Toplanması ve Analizi}

Araştırmada kullanılan veriler, çalışma alanı olarak seçilen belediyelerin stratejik planlarının 'peyzaj' ve 'yeşil alan' kavramlarının anahtar sözcük olarak kullanılıp taranmasıyla elde edilmiştir. Yapılan içerik analizi üç adımdan oluşmaktadır. Öncelikle açık-yeşil alanlara ilişkin politikalarının 
büyükşehir belediyelerinin kurumsal yapılarında nasıl yürütüldügünü tespit etmek amaciyla her bir kurumun stratejik plan verilerinde bulunan yeşil alanların dahil olduğu hizmet ve faaliyet alanı grupları saptanmış ve bu faaliyetleri yürüten sorumlu birimler Tablo 1.'de listelenmiştir. Daha sonra yönetimlerin peyzaj politikalarını belirlemek için peyzaj kavramının stratejik planlarda yer aldığı bölümler ve peyzaja ilişkin amaç, hedef ve performans göstergeleri belirlenerek değerlendirilmiştir. Son olarak, açık-yeşil alanları konu alan politikaları belirlemek için stratejik planlarda belediyelerin yeşil alanlarla ilişkilendirilebilecek şehircilik politikaları, çevre politikaları ve sosyal politikalarına ait amaçları hedefleri ve performans göstergeleri saptanmıştır. İncelemede "yeşil alan" anahtar kelime olarak seçilerek stratejik planlar taranmış, böylelikle yeşil alanlarla ilişkilendirilen yönetim stratejileri belirlenmiştir. Belirlenen stratejilerin içeriklerinin değerlendirilmesinde aşağıdaki kriterlere göre kategoriler oluşturulmuştur.

\section{Şehircilik Politikalarn:}

- Mekânsal planlama faaliyetleri; şehir planlama çalışmalarında yeşil alan planlamasına ilişkin veriler

- Kentsel tasarım/peyzaj projeleri; açık-yeşil alanlarda uygulanması planlanan projeler ve peyzaj projelerine ilişkin detaylar

- Kentsel dönüşüm projeleri; kentsel dönüşüm faaliyetlerinde açık-yeşil alanlarla ilgili stratejiler

\section{Çevre Politikalarn:}

- Ekolojik işlevlerin kullanılması; yeşil alanları ekolojik işlevleriyle ele alan stratejilere dair bilgiler

- Sürdürülebilirlik; sürdürülebilirlik hedeflerine ulaşmada yeşil alanların işlevlerinin kullanıldığı faaliyetler

- Koruma, iyileştirme ve artırma faaliyetleri; yeşil alanların korunması için yapılan uygulamalar bakım onarım çalışmaları, bitkilendirme çalışmalarına dair bilgiler

\section{Sosyal Politikalar:}

- Park ve mesire alanı sayısı; halkın rekreasyon ihtiyacını karşılayan alanlara dair bilgiler

- Kişi başına düşen yeşil alan miktarı: kentte kişi başına düşen yeşil alan miktarına ilişkin veri 
Oluşturulan kategorilerle yerel şehircilik, çevre ve sosyal politikalarda yeşil alanlarda dair yönetim stratejilerinin varlığ incelenmiştir. Her bir büyükşehir belediyesinin stratejik planında yer alan açık-yeşil alanlarla ilgili amaç ve hedeflere ilişkin veriler derlenmiş, bahsi geçen gruplandırma kriterlerine göre Tablo 2.'de gösterilmiştir. Tablonun oluşturulmasında her bir belediyenin stratejik planında seçilen kriterlere ilişkin bilgiler mevcutsa " " sembolü kullanılmış. Mevcut değilse “_" sembolü kullanılmıştır. Araştırma, büyükşehir belediyeleri tarafından hazırlanıp yayınlanan 5 yıllık stratejik planlarda yer alan açı-yeşil alanlara ilişkin politika ve faaliyetlerle sınırlandırılmıştır. Kurumlar tarafından yürütülen, stratejik planlarda belirtilmemiş hizmet ve faaliyetler incelemeye alınmamıştır.

\section{Bulgular}

Büyükşehir belediyelerinin 2020-2024 dönemi stratejik planları incelediğinde görülmektedir ki, yönetimler yerel politikalarının şekillenmesinde ulusal politika belgelerinin esas alındığını göstermek amacıyla planlarda 'Üst politika analizi' ve 'mevzuat analizi' başlıklı bölümlere yer vermişlerdir. Peyzaja ve yeşil alanlara ilişkin yerel politikaların oluşumunda 30 büyükşehir belediyesi tarafından referans gösterilen ulusal politika stratejisi 11. Kalkınma Planı'nın 632, 675 ve 676 sayılı maddeleridir. Ayrıca Çevre ve Şehircilik Bakanlığı'nın KENTGES planı (2009) ve her bir il için hazırlanan il çevre düzeni planlarının yeşil alanlara ilişkin maddeleri planlarda yerel politikalarının oluşturulmasında üst politika belgeleri analizinde yer almışlardır.

\section{Yerel Yönetim Stratejilerinde Yeşil Alanların Yer Aldığı Hizmet ve Fa- aliyet Alanları ve Faaliyetlerden Sorumlu Birimlerin Belirlenmesi}

Belediyelerin hizmet ve faaliyet alanları oluşumunda yeşil alanlara dair uygulamaların nasıl gruplandırıldığı ve yürütülen uygulamalardan kurumun teşkilat yapısındaki hangi birimin sorumlu olduğunu tespit etmek için stratejik planlar incelenmiştir. Tablo.1 her bir büyükşehir belediyesinin yeşil alanlarla ilişkin iş ve işleyişi kapsayan faaliyet alanlarını ve yerel yönetim hiyerarşisinde hizmet ve faaliyetleri yürüten birimleri içermektedir. 
Tablo 1. Yerel yönetim stratejilerinde yeşil alanların yer aldı̆̆ı hizmet ve faaliyet alanlar ve sorumlu birimler

\begin{tabular}{|c|c|c|}
\hline $\begin{array}{l}\text { Büyükşehir } \\
\text { Belediyesi (BŞB) }\end{array}$ & Hizmet / Faaliyet Alanı & $\begin{array}{l}\text { Sorumlu Birim/ } \\
\text { Daire Başkanlığı (DB) }\end{array}$ \\
\hline Adana BŞB. & Çevre ve Enerji Yönetimi & $\begin{array}{l}\text { Park Bahçeler DB. } \\
\text { Peyzaj Planlama ve Tasarım Şube Müd. }\end{array}$ \\
\hline Ankara BŞB. & Park Bahçe ve Yeşil Alanlar & $\begin{array}{l}\text { Çevre Koruma Kontrol DB. } \\
\text { Yeşil Alanlar Şube Müdürlüğü }\end{array}$ \\
\hline Antalya BŞB. & Çevre Yönetimi & $\begin{array}{l}\text { Park ve Bahçeler DB. } \\
\text { Yeşil Alanlar Bakım ve Onarım Şube Müd. }\end{array}$ \\
\hline Aydın BŞB. & Çevre Yönetimi & Çevre Koruma Kontrol DB. \\
\hline Balıkesir BŞB. & Şehir ve Çevre & Kent Estetiği DB. \\
\hline Bursa BŞB. & $\begin{array}{l}\text { Yeşil Alan ve Çevre Hizmetleri } \\
\text { Yönetimi }\end{array}$ & Park ve Bahçeler Şube Müdürlüğü \\
\hline Denizli BŞB. & Çevre ve Sağlık Hizmetleri & Park ve Bahçeler DB. \\
\hline Diyarbakır BŞB. & Çevre Yönetimi & Park Bahçeler DB. \\
\hline Erzurum BŞB. & Çevre Yönetimi & $\begin{array}{l}\text { Fen İşleri DB. } \\
\text { Park ve Bahçeler Şube Müdürlüğü }\end{array}$ \\
\hline Eskişehir BŞB. & Park ve Bahçeler & Park ve Bahçeler DB. \\
\hline Gaziantep BŞB. & İmar ve Şehircilik & Fen İşleri DB. \\
\hline Hatay BŞB. & Çevre ve Su Yönetimi & Park Bahçe ve Yeşil Alanlar DB \\
\hline İstanbul BŞB. & $\begin{array}{l}\text { Yeşil Alan ve Çevre Hizmetleri } \\
\text { Yönetimi }\end{array}$ & Park Bahçe ve Yeşil Alanlar DB. \\
\hline İzmir BŞB. & Alt Yap1 & Park Bahçe ve Yeşil Alanlar DB. \\
\hline $\begin{array}{l}\text { Kahramanmaraş } \\
\text { BŞB. }\end{array}$ & Çevre ve Sağlık Hizmetleri & Fen İşleri DB \\
\hline Kayseri BŞB. & Yeşil Alan ve Çevre Hizmetleri & Park Bahçeler ve Ağaçlandırma DB. \\
\hline Kocaeli BŞB. & $\begin{array}{l}\text { Sürdürülebilir Çevre Hizmet- } \\
\text { leri }\end{array}$ & Park Bahçeler ve Yeşil Alanlar DB. \\
\hline Konya BŞB. & Çevre Yönetimi & Park Bahçeler ve Yeşil Alanlar DB. \\
\hline Malatya BŞB. & $\begin{array}{l}\text { Çevre, Tarım ve Sağlık Yöne- } \\
\text { timi }\end{array}$ & $\begin{array}{l}\text { Çevre Koruma Kontrol DB. } \\
\text { Park Bahçeler Şube Müdürlüğü }\end{array}$ \\
\hline Manisa BŞB. & $\begin{array}{l}\text { Kent Yönetimi ve Kentsel Tasa- } \\
\text { rim }\end{array}$ & Kent Estetiği DB. \\
\hline Mardin BŞB. & $\begin{array}{l}\text { İmar Uygulamaları ve } \\
\text { Mekânsal Tasarım }\end{array}$ & İmar ve Şehircilik DB. \\
\hline Mersin BŞB. & Çevre ve Sağlık Hizmetleri & Park Bahçeler DB. \\
\hline Muğla BŞB. & Fen Hizmetleri & Fen İşleri DB \\
\hline Ordu BŞB. & $\begin{array}{l}\text { Çevre ve Sağlık Hizmetleri Yö- } \\
\text { netimi }\end{array}$ & Parklar ve Yeşil Alanlar DB. \\
\hline Sakarya BŞB. & Çevre Yönetimi & Çevre Koruma ve Kontrol DB. \\
\hline Samsun BŞB. & $\begin{array}{l}\text { Çevre, Temizlik ve Yeşil Alan } \\
\text { Yönetimi }\end{array}$ & Park Bahçeler DB. \\
\hline Şanlıurfa BŞB. & Çevre Yönetimi & Park Bahçeler DB. \\
\hline Tekirdağ BŞB. & Çevre Sağlık ve Esenlik & Park Bahçeler DB. \\
\hline Trabzon BŞB. & Yeşil Alan Yönetimi & Park Bahçeler DB. \\
\hline Van BŞB. & Sürdürülebilir Çevre Yönetimi & Park Bahçeler DB. \\
\hline
\end{tabular}


Büyükşehir belediyelerinin 17 'sinde yürütülen yeşil alan uygulamalarının faaliyet alanı çevre yönetimi başlığında gruplandırılmıştır. Çevre yönetimi, çevre ve sağlık hizmetleri yönetimi ya da sürdürülebilir çevre yönetimi faaliyet alanlarında yer alan yeşil alanlara ilişkin hizmetlerin yürütücülüğü kurumların teşkilat yapılanmasında Park Bahçeler Daire Başkanlığı mevcutsa Park Bahçeler Daire Başkanlı̆̆g'na, mevcut değilse çevre koruma ve kontrol daire başkanlığına verilmiştir.

30 büyükşehir belediyesinden 19'unda yeşil alanlar park bahçeler daire başkanlıklarının sorumluluğundadır. Bu daire başkanlıklarının görev tanımları mevcut yeşil alanlar oluşturmak, bitkilendirme çalışmaları yürütmek ve kentlerdeki park ve rekreasyon alanlarının bakım onarım çalışmalarını sürdürmek olarak tanımlanmıştır.

Ankara, Bursa, İstanbul, Kayseri, Samsun ve Trabzon belediyeleri yeşil alan yönetimini faaliyet alanlarında ayrı bir başlıkta değerlendirirken, Eskişehir Belediyesi ise stratejik planının hizmet alanlarında park ve bahçeler başlığını oluşturmuştur. Balıkesir Büyükşehir Belediyesi, yeşil alanlara şehir ve çevre konulu faaliyet alanlarında yer verirken, Manisa ise kent yönetimi ve kentsel tasarım başlığında ele almış her iki belediye de sorumlu birim olarak Kent Estetiği Daire Başkanlığı'nı belirlemiştir. İzmir Büyükşehir Belediyesi, yeşil alanlara ilişkin ürün ve hizmetlerini diğer tüm mekânsal planlama ve kentsel tasarım faaliyetleriyle birlikte 'alt yapı' başlıklı faaliyet alanında konumlandırmıştır.

\section{Stratejik Planlarda Yer Alan Peyzaja İlişkin Politikalar}

Yerel yönetimlerde peyzaj politikasının işleyişini görmek amacıyla 20202024 dönemi stratejik planları 'peyzaj' anahtar kelimesi kullanılarak taranmıştır. İnceleme sonucunda birkaç istisna dişında yerel yönetimlerin kentsel ya da kırsal peyzaj yönetimi için strateji geliştirmedikleri, peyzaj kavramına amaç, hedef ve performans göstergelerinde yer vermedikleri gözlemlenmiştir. Peyzaj kavramını içeren stratejik planlarda ise, peyzajın korunması, yönetimi ve planlanmasına yönelik hizmet ve faaliyetlerin geliştirilmediği görülmektedir.

İstanbul Büyükşehir Belediyesi Stratejik Planı'nda (2019), İstanbul Bölge Planı'nda bulunan kararlardan "İstanbul belleğini oluşturan öğele- 
rin, somut ve somut olmayan kültürel mirasın tarihi kentsel peyzaj yaklaşımıyla korunması" ifadesine üst politika analizi bölümünde yer verilse de bahsi geçen kentsel peyzaj yaklaşımına planda değinilmemiştir.

Kayseri Büyükşehir Belediyesi Stratejik Planı (2019) ise, “Çağdaş şehircilik ilkelerine dayanarak kentin eskiyen, çöküntü haline dönüşen kısımlarını vatandaşların ihtiyaçları, kentsel peyzaj, kentsel estetik, erişilebilirlik, sürdürülebilirlik, yaşana bilirlik, kullanılabilirlik gibi kavramların dikkate alınarak yenilenmesinin sağlamak" ifadesine imar ve şehircilik hizmetleri yönetiminde yer verse de stratejik amaç ve hedeflerde peyzaj kavramina yer vermemiştir.

Öte yandan, Mardin Büyükşehir belediyesi, çevre koruma ve su yönetimi faaliyet alanında peyzaj çalışmaları yapılmasına hedef kartlarında yer vermiş (Mardin Büyükşehir Belediyesi, 2019), Muğla ve Ordu Büyükşehir Belediyeleri ise yeşil alanlarda yürüttükleri projeler ve bakım onarım çalışmalarını performans göstergelerinde peyzaj bakım onarım çalışmaları ve peyzaj projeleri olarak adlandırmışlardır.

30 Büyükşehir belediyesi arasından yalnızca Mersin, erişilebilir yeşil alan planlamasının gerçekleştirmeyi amaçlayan 2.1. numaralı stratejik hedefinin faaliyetlerinde "Yeşil Mersin projesi ve peyzaj master planı doğrultusunda bitkilendirme çalışmaları" (Mersin Büyükşehir Belediyesi, 2019) açıklamasına yer vererek peyzaj yönetiminde peyzaj master planının kullanıldığını beyan eden tek belediye olmuştur.

\section{Yeşil Alanların Yer Aldığı Stratejik Hedef Amaç ve Performans Göster- gelerinin Değerlendirilmesi}

Tablo 2. büyükşehir belediyelerince yürütülen politikalara dair stratejik planlarda sunulan amaç, hedef ve performans göstergeleri belirlenerek, bu politikalarla yeşil alanların ilişkisini ortaya koymak için oluşturulmuştur. Belediyelerin stratejik planlarının değerlendirilmesinde içerik analizi için kategorilere ayrılan şehircilik politikaları, çevre politikaları ve sosyal politikalarda açık-yeşil alanlarla ilgili faaliyetlere dair bilgilerin yer alıp almadığ 1 incelenmiş, gruplandırma 30 büyükşehir belediyesinin kurumsal dokümanlarında bulunan verilere dayandırılarak yapılmıştır. 
Tablo 2. Büyükşehir belediyelerinin stratejik planlarında yer alan yeşil alanlara ilişkin amaç hedef ve performans göstergeleri ve yerel politikaları ilişkisi

\begin{tabular}{|c|c|c|c|c|c|c|c|c|}
\hline \multirow[b]{2}{*}{$\begin{array}{l}\text { Büyükşehir Beledi- } \\
\text { yesi (BŞB) }\end{array}$} & \multicolumn{3}{|c|}{ Şehircilik Politikaları } & \multicolumn{3}{|c|}{ Çevre Politikaları } & \multicolumn{2}{|c|}{ Sosyal Politikalar } \\
\hline & 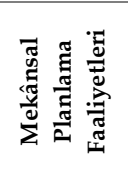 & 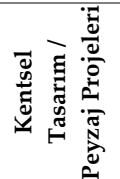 & 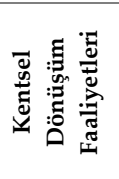 & 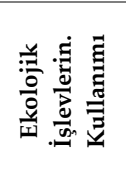 & 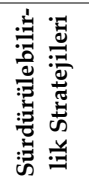 & 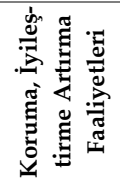 & 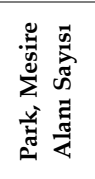 & 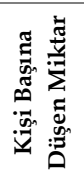 \\
\hline Adana BŞB. & - & $\sqrt{ }$ & - & - & $\sqrt{ }$ & $\sqrt{ }$ & $\sqrt{ }$ & - \\
\hline Ankara BŞB. & - & - & - & $\sqrt{ }$ & - & $\sqrt{ }$ & $\sqrt{ }$ & $\sqrt{ }$ \\
\hline Antalya BŞB. & - & $\sqrt{ }$ & - & - & - & $\sqrt{ }$ & $\sqrt{ }$ & $\sqrt{ }$ \\
\hline Aydın BŞB. & - & - & - & $\sqrt{ }$ & - & $\sqrt{ }$ & - & $\sqrt{ }$ \\
\hline Balıkesir BŞB. & $\sqrt{ }$ & $\sqrt{ }$ & $\sqrt{ }$ & - & $\sqrt{ }$ & $\sqrt{ }$ & $\sqrt{ }$ & - \\
\hline Bursa BŞB. & - & - & - & - & $\sqrt{ }$ & $\sqrt{ }$ & - & $\sqrt{ }$ \\
\hline Denizli BŞB. & - & - & - & - & $\sqrt{ }$ & $\sqrt{ }$ & $\sqrt{ }$ & - \\
\hline Diyarbakır BŞB. & $\sqrt{ }$ & - & - & - & $\sqrt{ }$ & $\sqrt{ }$ & $\sqrt{ }$ & $\sqrt{ }$ \\
\hline Erzurum BŞB. & - & $\sqrt{ }$ & - & - & $\sqrt{ }$ & $\sqrt{ }$ & $\sqrt{ }$ & $\sqrt{ }$ \\
\hline Eskişehir BŞB. & - & - & - & $\sqrt{ }$ & $\sqrt{ }$ & $\sqrt{ }$ & $\sqrt{ }$ & - \\
\hline Gaziantep BŞB. & - & - & - & - & - & $\sqrt{ }$ & - & $\sqrt{ }$ \\
\hline Hatay BŞB. & - & - & - & $\sqrt{ }$ & - & $\sqrt{ }$ & $\sqrt{ }$ & $\sqrt{ }$ \\
\hline İstanbul BŞB. & $\sqrt{ }$ & - & - & $\sqrt{ }$ & $\sqrt{ }$ & $\sqrt{ }$ & - & $\sqrt{ }$ \\
\hline İzmir BŞB. & $\sqrt{ }$ & $\sqrt{ }$ & $\sqrt{ }$ & $\sqrt{ }$ & $\sqrt{ }$ & $\sqrt{ }$ & $\sqrt{ }$ & - \\
\hline $\begin{array}{l}\text { Kahramanmaraş } \\
\text { BŞB. }\end{array}$ & - & $\sqrt{ }$ & - & - & - & $\sqrt{ }$ & $\sqrt{ }$ & - \\
\hline Kayseri BŞB. & - & $\sqrt{ }$ & - & - & - & $\sqrt{ }$ & $\sqrt{ }$ & $\sqrt{ }$ \\
\hline Kocaeli BŞB. & - & - & - & - & - & $\sqrt{ }$ & $\sqrt{ }$ & $\sqrt{ }$ \\
\hline Konya BŞB. & - & $\sqrt{ }$ & - & $\sqrt{ }$ & - & $\sqrt{ }$ & $\sqrt{ }$ & $\sqrt{ }$ \\
\hline Malatya BŞB. & - & - & - & - & - & $\sqrt{ }$ & - & $\sqrt{ }$ \\
\hline Manisa BŞB. & $\sqrt{ }$ & $\sqrt{ }$ & - & - & $\sqrt{ }$ & $\sqrt{ }$ & $\sqrt{ }$ & $\sqrt{ }$ \\
\hline Mardin BŞB. & $\sqrt{ }$ & $\sqrt{ }$ & - & - & $\sqrt{ }$ & - & - & - \\
\hline Mersin BŞB. & - & $\sqrt{ }$ & - & $\sqrt{ }$ & - & $\sqrt{ }$ & - & $\sqrt{ }$ \\
\hline Muğla BŞB. & - & $\sqrt{ }$ & - & - & - & $\sqrt{ }$ & - & $\sqrt{ }$ \\
\hline Ordu BŞB. & - & $\sqrt{ }$ & $\sqrt{ }$ & - & - & $\sqrt{ }$ & $\sqrt{ }$ & $\sqrt{ }$ \\
\hline Sakarya BŞB. & $\sqrt{ }$ & $\sqrt{ }$ & - & - & - & $\sqrt{ }$ & $\sqrt{ }$ & $\sqrt{ }$ \\
\hline Samsun BŞB. & $\sqrt{ }$ & $\sqrt{ }$ & - & - & - & $\sqrt{ }$ & - & - \\
\hline Şanlıurfa BŞB. & - & - & - & - & - & $\sqrt{ }$ & - & $\sqrt{ }$ \\
\hline Tekirdağ BŞB. & - & $\sqrt{ }$ & - & - & - & $\sqrt{ }$ & $\sqrt{ }$ & $\sqrt{ }$ \\
\hline Trabzon BŞB. & - & - & - & - & - & $\sqrt{ }$ & - & - \\
\hline Van BŞB. & - & $\sqrt{ }$ & - & $\sqrt{ }$ & $\sqrt{ }$ & $\sqrt{ }$ & - & $\sqrt{ }$ \\
\hline
\end{tabular}

Stratejik planlarda yer alan yeşil alanlara ilişkin şehircilik politikaları: Büyükşehir belediyelerinin şehircilik politikalarına ilişkin stratejik plan verileri incelendiğinde görülmektedir ki peyzaj planlama ya da bütüncül 
ve sistematik açık-yeşil alan planlama stratejileri belediyelerin politikalarında yer almamaktadır. Şehir planlama uygulamalarında büyükşehir belediyelerinden yalnızca 8'i stratejik amaç ve hedeflerinde yeşil alan planlaması konusunu ele almıştır. Tüm belediyeler kentlerdeki yeşil alan miktarını artırmayı stratejik amaç olarak belirlese de bu stratejinin mekânsal planlara nasıl yansıtılacağı planlarda detaylandırılmamıştır. Yeşil alan planlamasına ilişkin amaç ve hedef belirleyen belediyelerden Mersin Büyükşehir Belediyesi (2019) "Yeşil Mersin projesi ve Peyzaj Master planı doğrultusunda bitkilendirme çalışmaları" ifadesiyle peyzaj planlamaya imar ve şehircilik stratejilerinde yer vermiştir. Manisa'da ise koruma amaçlı imar planı yapımı ve kentsel sit alanlarında yeşil alanların düzenlenmesi hedefi, planlama uygulamalarının performans göstergesi olarak belirlenmiştir (Manisa Büyükşsehir Belediyesi, 2019). İstanbul Büyükşehir Belediyesi'nin şehircilik stratejilerinde ise her ne kadar yeşil alan planlama çalışmalarının detayları verilmese de "Gerektiğinde yeni yeşil alan oluşturulabilmesi için kamulaştırma çalışmalarının yapılması" (İstanbul Büyükşehir Belediyesi, 2019) hedefi yer almıştır. Stratejik planında sistematik bir yeşil alan planlama stratejisine yer veren tek belediye ise İzmir Büyükşehir Belediyesi'dir. Belediye "Herkesi kapsayan sürdürülebilir bir alt yapı oluşturmak" amacıyla kentte yürütülen alt yapı çalışmaları için belirlenen "Yeşil alt yapı: il genelinde iklim dostu yeşil alanlar ağı oluşturulacak" (İzmir Büyükşehir Belediyesi, 2019) performans göstergesiyle, mekânsal planlarında bütüncül bir yeşil altyapı sistemi geliştireceğini beyan eden tek belediye olmuştur.

Yeşil alanları tasarlama ve uygulama projelerine ilişkin bilgilere 30 büyükşehir belediyesinden 17 'sinin stratejik planlarında yer verilmiştir. Yürütülen faaliyetlerde 11. Kalkınma Planı'nın (2019) yeşil şehir vizyonu referans gösterilmiştir. Fakat projelerin açıklamaları, yapılması planlanan rekreasyon alanlarının konumları ve büyüklüklerine dair veriler içermekte, bu içerik belediyelerin kentteki yeşil alan miktarını arttırmak hedeflerine karşılık gelmektedir. Fakat stratejik planlarda oluşturulacak yeşil alanların detaylarına yer verilmesine rağmen projelerin peyzaj projesi olarak tanımlamadığı görülmektedir. Örneğin; Kayseri Büyükşehir Belediyesi 2020-2024 Stratejik Planı'nda (2019) peyzaj projeleri 'çevre düzenleme projeleri' olarak adlandırılmış ve yapılan uygulamalar kent estetiğine katkı sağlama perspektifinde değerlendirilmiştir. Yerel yönetimlerce 
uygulanması planlanan peyzaj projeleri; kentsel tasarım, yeşil alan düzenlemesi veya çevre düzenleme projeleri olarak adlandırılmışlardır. Yalnızca Kahramanmaraş, Mardin, Muğla ve Ordu Büyükşehir Belediyelerinin stratejik planlarında yeşil alanlara ilişkin projeler peyzaj projesi olarak nitelendirilmiştir.

Belediyeler, kentsel dönüşüm projelerinde ise 6306 sayılı Afet Riski Altındaki Alanların Dönüştürülmesi Hakkında Kanun gereğince dönüşüm yapılacak alanlar ve kamulaştırma işlemlerine dair belirlenen hedefleri stratejik planlarında bildirmişlerdir. Fakat yalnızca Balıkesir, İzmir ve Ordu Büyükşehir Belediyeleri stratejik planlarında kentsel dönüşüm stratejilerine yeşil alanların da dahil olacağını ifade etmişlerdir. Her ne kadar kentsel dönüşüm uygulamalarına yeşil alanların nasıl entegre edileceği planlarda açıklanmasa da Balıkesir Büyükşehir Belediyesi 2020-2024 stratejik planının hazırlık aşamasında oluşturulan şehir politikalarının analizi raporunda yer alan kentsel dönüşüm önerilerinde "rekreasyon alanlarında ekolojik kriterlere uyulması" (Balıkesir Büyükşehir Belediyesi, 2019) önerisine stratejik planda yer vermiştir. Ordu Büyükşehir Belediyesi Stratejik Planı'nda (2019) "İlimizin doğal değerlerini, tarihi-kültürel mirasını koruyarak planlı, düzenli gelişimi için kentsel dönüşüm ve tasarımını sağlamak" amacını gerçekleştirmek için peyzaj projeleri uygulamak ve rekreasyon alanları oluşturmayı performans göstergesi olarak belirlenmiştir. İzmir Büyükşehir Belediyesi ise stratejik planında kentsel dönüşüm ve yeşil alanlara yönelik çalışmaları 'alt yapı' başlıklı aynı faaliyet alanında ele alarak, kentsel dönüşüm uygulamalarının doğayı ve ekolojik dengeyi gözeterek yapılacağını beyan etmiştir (İzmir Büyükşehir Belediyesi, 2019).

Stratejik planlarda yer alan yeşil alanlara ilişkin çevre politikalarn: Her ne kadar yerel yönetimler üst politika belgeleri analizlerinde yeşil şehir vizyonunu temel alıp, yeşil alanları artıracak eylemlere stratejik planlarda yer verseler dahi bu uygulamalarda yeşil alanların sağladığı ekosistem servislerini göz ardı ettikleri ve açık-yeşil alanların ekolojik işlevlerini sağlıklı ve sürdürülebilir bir çevre oluşturmayı hedefleyen yerel çevre politikalarında değerlendirmedikleri görülmektedir. Büyükşehir belediyelerinin 9'u, Ankara, Aydın, Eskişehir, Hatay, İstanbul, İzmir, Konya Mersin ve Van Büyükşehir Belediyeleri, yerel politikalarda yeşil alanların ekolojik işlevlerinin kullanılmasına yönelik amaç ve hedeflere yer vermiştir. Bu 9 
belediye, iklim değişikliği etkilerini azaltma, hava kalitesini iyileştirme ve ekolojik dengeyi koruma hedeflerinin gerçekleştirilmesinde yeşil alanların korunmasını ve miktarının artırılmasını planlamışlardır.

2020-2024 stratejik plan döneminde, çevre politikalarında yeşil alanların ekolojik katkılarını göz önünde bulunduran stratejik planlarda yeşil alanların yer aldığı hedefler aşağıda sıralanmıştır.

- Ankara Büyükşehir Belediyesi Stratejik Planı'nda “Doğa ve hayvan dostu bir yönetim anlayışı ile ekolojik dengeyi koruyan, biyolojik çeşitliliği destekleyen, etkili bir atık yönetimi ile yenilenebilir enerji politikalarını esas alan, sürdürülebilir çevre yönetimini benimsemiş, iklim değişikliklerinin olumsuz etkilerinin farkında bir kent oluşturmak"(2019),

- Aydın Büyükşehir Belediyesi Stratejik Planı'nda "ekosistem dengesi koruma kapsamında çevre kirliliğinin azaltılması ve yeşil alanların artırılması"(2019),

- Eskişehir Büyükşehir Belediyesi Stratejik Planı'nda, "Eskişehir'in iklim değişikliğine duyarlılığını arttırmak" (2019),

- Hatay Büyükşehir Belediyesi Stratejik Planı'nda "Küresel iklim değişikliğinin neden ve etkilerini önleyici tedbirler alınmasi"(2019),

- Konya Büyükşehir Belediyesi Stratejik Planı'nda “yeşil şehir vizyonuyla yeşil alan miktarını artırarak şehrin hava kalitesinin iyileştirilmesini sağlamak"(2019),

- İstanbul Büyükş̧ehir Belediyesi Stratejik Planı'nda "İklim değişikliği ile mücadeleyi yaygınlaştırarak çevreyi korumak" (2019),

- İzmir Büyükşehir Belediyesi Stratejik Planı'nda "İl genelinde iklim dostu yeşil alanlar ağı oluşturulacak" (2019),

- Mersin Büyükşehir Belediyesi Stratejik Planı'nda "Kentte sağlık hizmetleri ve kaliteli yaşam hizmetleri, sürdürülebilir çevre ve ekolojik korumayı destekleyen hizmet sunumunun sağlanmasi"(2019),

- Van Büyükşehir Belediyesi Stratejik Planı'nda "var olan canl1cansız çevre ilişkisinin ve kent yaşam kalitesinin yönetimi, korunması, geliştirilmesi doğrultusunda ekolojik bir toplum inşası"(2019). 
Büyükşehir belediyeleri bahsi geçen stratejik amaçlarla yerel politikalarında kentsel açık-yeşil alanların ekolojik işlevlerine ilişkin stratejiler geliştirmişlerdir.

Büyükşehir Belediyelerinin tamamı 2020-2024 stratejik planlarında sürdürülebilir çevrenin sağlanmasına yönelik politikalar yürüttüklerini beyan etseler dahi kentsel peyzaj veya açık-yeşil alanlar, sürdürülebilirliğin sağlanması hedeflerine 12 belediyenin stratejik planında dahil edilmiştir. Adana, Balıkesir, Bursa, Denizli, Diyarbakır, Erzurum, Eskişehir, İstanbul, İzmir, Manisa, Mardin ve Van Büyükşehir Belediyeleri, yaşanabilir mekânlar ve sürdürülebilir bir çevre oluşturmak genel konseptiyle belirledikleri amaçlarla kentteki yeşil alanların korunması ve çoğaltılmasını hedeflemişlerdir. Fakat planlarda çevre politikaları ve sürdürülebilirlik kriterleri uyumunun nasıl sağlanacağına dair açıklamalar yer almamıştir.

11. Kalkınma Planı (2019) 675. ve 676.maddeleri esas alınarak yeşil alanları koruma, miktarını artırma ve standartlarını iyileştirmeyi hedefleyen 30 büyükşehir belediyesinin tamamı, stratejik planlarında bu amaca yönelik performans göstergeleri oluşturmuşlardır. Belediyeler 5 yıllık plan dönemi boyunca yapılması planlanan park, mesire alanı, kent ormanı ve benzeri açık-yeşil alan oluşturma projelerinde alanların yüzölçümlerine, konumlarına ve projelerin gerçekleşmesi için gerekli mali kaynak verilerine planlarda yer vermişlerdir. Yalnızca Mardin Büyükşehir Belediyesi Stratejik Planı'nda (2019) yeşil alanların artırılmasına yönelik bir performans göstergesi bulunmamakta, yaşanabilir mekânlar oluşturmak amacında, parklardaki sosyal donatıların artırılmasına yönelik faaliyetler bulunmaktadir.

Stratejik planlarda yer alan yeşil alanlara ilişkin sosyal politikalar: Yeşil alan miktarının artırılması, park ve bahçelere toplumun her kesiminin erişiminin sağlanması ve engelsiz parklar yapımı belediyelerin yeşil alanlara ilişkin en yaygın politikalarını oluşturmaktadır. Büyükşehir belediyelerinin $18^{\prime}$ i şehirlerde bulunan mevcut rekreasyon alanları ile yapılması planlanan yeni parklara dair bilgilere planlarda yer vermiştir. Özellikle, parklarda yer alan çocuk oyun alanları, spor alanları ve diğer sosyal donatılarla ilişkili faaliyetler planlarda bulunmaktadır. 
Stratejik planlarda oluşturulan hedef kartlarında, yeşil alanlar konusunda en yaygın performans göstergesi ‘kişi başına düşen yeşil alan miktarının artırılması' hedefidir. 21 belediyenin stratejik planında bu miktarın artırılması için faaliyetler yürütüldügü belirtilmiştir. Kişi başına düşen yeşil alan miktarının performans göstergesi olarak planlarda yer almasının sebebi, imar mevzuatınca miktarın $10 \mathrm{~m}^{2}$ olarak belirlenmiş olmasıdır. Belediyeler yaşanılabilir çevreyi oluşturmak hedeflerini çevre politikaları ve sosyal politikalarına dayandırmışlar, raporlarında topluma yeterli rekreasyon alanı sağlamaya yönelik hizmetleri sunacaklarını belirtmişlerdir.

\section{Tartışma ve Sonuç}

30 büyükşehir belediyesinin stratejik planlarında yer alan yeşil alanlara ilişkin politikalarının incelenmesiyle açık-yeşil alanların planlanması, korunması ve yönetiminde uygulamaların yetersiz olduğu ve yönetim stratejilerinde eksiklikler bulunduğu gözlemlenmiştir. İncelemede yalnızca stratejik planlarda bulunan bilgiler değerlendirildiğinden, belediyelerin tarafından yürütülen faaliyetlerin tamamının incelenmesi mümkün olamamıştır. Stratejik planlarda üst politika belgeleri analizinde 11. Kalkınma Planı ve Çevre ve Şehircilik Bakanlığı'nın politika belgelerine yer verilmiştir. 11. Kalkınma Planı'nda (2019) Şehirleşme başlığında yer alan yeşil alanlara, Kültür ve Sanat başlığında ele alınan peyzaja ilişkin stratejiler yerel yönetimlerin performans göstergelerine yansımamış, yerel ölçekte karşılık bulamamıştır. Stratejik planla belirtilen amaç ve hedeflerin uygulanıp uygulanmadığını tespit etmek için ise stratejik planların takibini sağlayan kurumların yıllık performans programları ve faaliyet raporlarında yer alan veriler incelenmelidir.

Açı-yeşil alanlara ilişkin faaliyet alanlarını 'çevre yönetimi' başlığında gruplandıran belediyelerde, yeşil alan planlamasına dair stratejilerin yer almadığı görülmektedir. Faaliyet alanını 'yeşil alan yönetimi' olarak belirleyen yönetimler nispeten daha nitelikli bir yönetim stratejisi ortaya koymuşlardır. Fakat şehircilik politikalarına entegre bir yeşil alan yönetim sistematiği İzmir Büyükşehir Belediyesi Stratejik Planı dışında başka hiçbir stratejik planda yer almamıştır. Belirlenen yeşil alan yönetim stratejilerinin uygulanmasında teşkilat yapısındaki iş bölümlerinden kaynaklanan problemler mevcuttur. Planlama aşamasını genellikle İmar ve Şehircilik 
Daire Başkanlıkları yürütürken, kentsel peyzaj projelerini Etüt ve Projeler Daire Başkanlıkları ve Fen İşleri Daire Başkanlıkları yürütmektedir. Yeşil alanlardan sorumlu birim olarak görevlendirilen Park Bahçeler Daire Başkanlıkları ise yalnızca yeşil alanlardaki bitkilendirme ve bakım çalışmalarında yetki sahibi olmaktadırlar. Peyzaj mimarı istihdamı belediyelerde en çok Park ve Bahçeler Daire Başkanlıkları'nda yapılmaktadır. Bu durum yeşil alanların planlanması ve projelendirilmesi faaliyetlerinde mesleki yeterliliğe sahip uzmanlar olan peyzaj mimarlarının söz sahibi olamadığ1nın kanitıdır. Yönetim hiyerarşisinde görülen koruma, planlama ve tasarım faaliyetlerinde birden çok birimin yetkili olması yeşil alanların sistematik bir şekilde yönetilmediğinin, uygulamaların farklı birimler bünyesinde devam ettirilip efektif ve bütüncül olarak işleyemediğinin göstergesidir.

Yerel peyzaj politikalarına ilişkin yapılan incelemede, peyzaj politikasının kavramsal olarak yönetimlerin stratejilerinde bulunmadığı görülmüştür. Politika oluşturulması bir yana peyzaj kelimesi dahi stratejik planların çoğunda yer almamakta, peyzajın yer aldığı planlarda ise peyzaj tasarım projelerinin uygulanıp rekreasyon alanlarının tasarlanmasına dair hedefler bulunmaktadır. Bu durum peyzaj politikası kavramının ulusal politika belgelerinde dahi henüz yer almamış olmasından kaynaklanmaktadır.

Şehircilik politikalarının incelenmesi sonucunda; planlama çalışmalarında, imar mevzuatı gereğince yapılan nazım ve uygulama imar planı çalışmalarının detaylandııldığı görülmektedir. Stratejik planlarda, şehir planlama faaliyetlerinin açıklamalarında bütüncül bir yeşil alan sistemi planlamasından bahsedilmemiştir. Ayrıca kentsel peyzaj planlamada ekolojik yaklaşımları içeren kavramlar olan yeşil alt yapı, yeşil kuşak, yeşil koridor gibi bütüncül ve sistematik yeşil alan planlama stratejileri belediyelerin politika belgelerinde yer almamaktadırlar. Yalnızca İzmir Büyükşehir Belediyesi stratejik planında yeşil alt yapı ağı oluşturmayı hedeflemiş (2019), Mersin Büyükşehir Belediyesi ise peyzaj master planının yapılacağını bildirmiştir. Ayrıca uygulanması planlanan kentsel dönüşüm projelerinde yeşil alanlara ilişkin planlama ve tasarım verileri raporlarda yer almamaktadır. Yeşil alanları içeren en yaygın planlama hedefi olarak Mekânsal Planlar Yapım Yönetmeliği ile standardı belirlenen kişi başına 
düşen yeşil alan miktarının artırılması olmuş, bu amaca nasıl ulaşılacağına ilişkin detaylar stratejik planlarda yer almamıştır. Yeşil alanların tasarlandığı kentsel projelerde ise uygulanması planlanan ve sosyal donatılar içeren park ve mesire alanlarına dair veriler planlarda yer almıştır.

Çevre politikaları incelendiğinde yeşil alanların sağladığı ekosistem servislerinin ve kent ekolojisine faydalarının yerel yönetimlerce değerlendirilmediği görülmektedir. İklim değişikliğine karşı mücadelede yeşil alanların karbon tutma işlevini ve hava kirliliğini önleme işlevini kullanmayı hedefleyen birkaç istisnai belediye dışında bu konuya ilişkin stratejiler geliştirilmemiştir. Çevre ve Şehircilik Bakanlığı'nın İklim Değişikliği Eylem Planı'nda (2012), kentlerde yeşil büyüme hedefi yer alsa bile, belediyelerin birçoğu planlarda iklim değişikliği adaptasyonu, karbon salınımını düşürme ya da kentsel ısı adası oluşumuna karşı alınan tedbirlere yer vermemişlerdir. Bu durum merkezi politikaların yerele yansımasında aksaklıklar görülebileceğinin ispatı niteliğindedir. Yeşil alanların korunmasına yönelik uygulamalarda belediyeler sürdürülebilir, yaşanılabilir, sağlıklı bir çevre oluşturmak hedeflerini esas alarak yeşil alanların bakımonarımlarının yapılması ve iyileştirme faaliyetlerini içeren performans göstergeleri belirlemişlerdir. Bu performans göstergeleri bakımı yapılan rekreasyon alanları ve yeşil alanların yüz ölçümü ile sınırlandırılmıştır. Ayrıca iyileştirme ve yeni yeşil alanlar oluşturma hedeflerinde ise yapılan ağaçlandırma çalışmaları, dikilen fidan miktarı ve ekilen mevsimlik bitkilerin sayısı belirtilmiştir.

Sosyal politikaların incelenmesi neticesinde, belediyelerin yeşil alanları konu alan en yoğun çalışmalarının bu alanda olduğu gözlemlenmiştir. Halkın rekreasyon ihtiyaçlarını karşılamak, yeşil alanların erişilebilir olmasını sağlamak ve alanlarda bulunan sosyal donatıları artırmak için belediyeler, uyguladıkları kent parkı ve semt parkı projelerinin detaylarına planlarda yer vermişlerdir. Ayrıca yapılan meydan düzenlemeleri, yol kenarı bitkilendirmeleri ve ağaçlandırma çalışmalarıyla yeşil alanların estetik işlevlerini ele alıp, kişi başına düşen yeşil alan miktarının hesaplanmasına ve kent estetiğini iyileştirmeye yönelik çalışmaları da dahil etmişlerdir.

Büyükşehir belediyelerinin yerel politikalarının oluşum ve uygulanma kriterlerini içeren resmi dokümanlar niteliğini taşıyan stratejik planlarda 
incelendiğinde, kentsel açık-yeşil alanlarla ilgili amaç ve hedefler hakkındaki verilerin yetersiz olduğu gözlemlenmiştir. Belediyelerin birçoğu sağlıklı ve yaşanılabilir bir çevre oluşturmak amaçlarında toplumun rekreatif ihtiyaçlarını vurgulayarak yeşil alanları sosyal politikalar kategorisinde ele almışlar, sürdürülebilir çevre elde etmeyi hedefleyen belediyeler az sayıda olsalar bile yeşil alanları ekolojik işlevleri bakımından değerlendirmeyi planlamışlardır. Fakat yeşil alanların ekolojik işlevlerinin nasıl etkin hale getirileceğine ve yeşil alanların sunduğu ekosistem servislerinin verimliliğinin nasıl artırılacağına dair yönetim stratejilerine planlarda rastlamamıştır. Kentlerde gerçekleşmesi muhtemel kentleşme sorunlarına karşı alınacak önlemler arasında yeşil alanları içeren çözümlere yer verilmemiştir. Planlarda belirtilen mevcut politikalar peyzaja dair hedefleri içermekte fakat yeşil alanları çevre ve kentleşme sorunlarının çözümüne yönelik bir kavram olarak görmemektedir.

Bu nedenlerle peyzaj politikası kavramının diğer sektörlerdeki politikalarla etkileşimi incelenmeli ve peyzaj için oluşturulması gereken politik stratejilerin kriterleri belirlenmelidir. Ulusal ve yerel ölçeklerde peyzaj politikasının oluşumu için gerekli yasal düzenlemeler yapılmalı ve koruma, planlama ve yönetim aşamalarında yasal standartlar oluşturulmalıdır. Üst ölçekli planlarda peyzaj karakter analizleri yapılması ve imar planlarında açık-yeşil alanların bütüncül ve sistemli bir yaklaşımla planlanması, yaşanılabilir kent sürdürülebilir çevre hedeflerine ulaşılmasına önemli katk1larda bulunacaktır. Yerel yönetimlerce oluşturulacak stratejilerde, üst politika belgelerinde bulunan iklim değişikliğine uyum, ekosistem hizmetlerinin korunması ve yeşil şehir vizyonu kazanma gibi politikaların yer alması ve uygulamaya geçirilmesi ve üst politika belgelerinde peyzajın korunması planlanması ve yönetimine ilişkin stratejilerin geliştirilip detaylandırılması toplumun sağlıklı bir çevrede yaşayabilmesini sağlamak için elzem adımlardır. 


\title{
EXTENDED ABSTRACT
}

\section{An Evaluation of Urban Green Space Management Strategies of Local Governments in Turkey}

\author{
Venhar Melda Hassamancıŏ̆lu \\ Tokat Gaziosmanpaşa University
}

Open-green spaces contribute to cities with their ecological, economic, sociological and physical functions. Considering the functions of green spaces, it is seen that they offer many ecosystem services to urban life in the natural and cultural context. Ecosystem services have become an important tool, an overarching framework for policy-making and decisionmaking, particularly in landscape planning and natural resource management.

The aim of the study; evaluating the landscape policies of the local governments of metropolitan cities in Turkey, revealing the management strategies for open-green areas, examining the field of service and activity in which open-green areas are included, and questioning the existence of a holistic green area management system at local governments. In this study, the reflections of national landscape policies on local governments and open-green space management strategies of local governments in line with the determined policies were evaluated. 30 metropolitan municipalities in Turkey were selected as samples in the study. The place of green areas in the policies of selected metropolitan municipalities was examined. Since the concept of landscape policy is not yet widely used by the administrative units, the urban policies, environmental policies and social policies of the institutions were evaluated in the study. Document analysis method, which is a qualitative data analysis method, was used as the main method of this research. In the research, the current strategic plans of the municipalities were chosen as the material. Categories were determined for content analysis and the data in the documents were evaluated according to the categories of urbanization, environment and social policies.

In the evaluations made, in order to examine how landscapes are managed in municipalities, fields of service and activity were determined and it was specified that which unit is authorized for landscape management 
in municipalities. Open-green areas, which are mostly positioned under the title of environmental management, are under the authority of the parks and gardens departments.

When the urbanization policies are examined, it was seen that there was no mention of a holistic green space system planning in descriptions of city planning activities in strategic plans. In addition, holistic and systematic green space planning strategies such as green infrastructure, green belt, green corridor, which are concepts that include ecological approaches in urban landscape planning, are not included in the policy documents of municipalities. In city planning practices, only 8 of the metropolitan municipalities have addressed the issue of green space planning in their strategic goals and targets.

As a result of the examination of environmental policies, it was seen that the ecosystem services provided by green areas and their benefits to urban ecology are not evaluated by local governments. Except for a few municipalities that aim to use the carbon sequestration function of green areas and the function of preventing air pollution in the fight against climate change, no strategies have been developed in this regard.

With the examination of social policies, it has been observed that the services of the municipalities regarding green areas are mostly in the field of social policies. In strategic plans, the municipalities have included the details of the urban park and neighborhood park projects implemented with the aim of meeting the recreational needs of the society, making the green areas accessible and increasing the social facilities in the public spaces. Additionally, by addressing the aesthetic functions of green areas with square arrangements, roadside plantings and afforestation works, They also included these studies aimed at improving urban aesthetics in the calculation of the amount of green space per capita.

Consequently, it has been observed that the data on the goals and objectives of urban open-green spaces are insufficient by examining the strategic plans, which are the official policy documents of metropolitan municipalities. Many of the municipalities have emphasized the recreational needs of the society in order to create a healthy and livable environment and have discussed green areas in the category of social policies. There are few municipalities that aim to achieve a sustainable environment with planning to evaluate green areas in terms of their ecological functions. 
Even if they aim for this, management strategies on how to activate the ecological functions of green areas and how to increase the efficiency of the ecosystem services provided by green areas have not been found in the strategic plans. Among the measures to be taken against possible urbanization problems in cities, solutions including green areas were not included in strategic plans. Existing local policies determined in the plans include objectives related to the landscape but did not consider green spaces as a concept for solving environmental and urbanization problems.

For the solution of the problems identified in this study on landscape management and open green space management in local governments, necessary legal arrangements should be made for the formation of landscape policy at national and local scales. And legal standards should be established at the stages of protection, planning and management of landscapes. Strategies for increasing the quality and the quantity of urban landscape should be developed and detailed in national policy documents. The holistic open-green space planning systems should be founded in cities and units to manage this system effectively should be established in the municipalities. Local governments should develop and implement policies such as adapting to climate change, improving ecosystem services and gaining a green city vision. These policies are essential steps to ensure that society can live in a healthy environment.

\section{Kaynakça / References}

Adana Büyükşehir Belediyesi (2019). 2020-2024 Stratejik Planı, Adana.

Albayrak, I. (2012). Ekosistem servislerine dayal havza yönetim modelinin Istanbul- Ömerli Havzası örneğinde uygulanabilirliği. İTÜ Fen Bilimleri Enstitüsü, İstanbul.

Ankara Büyükşehir Belediyesi (2019). Stratejik Plan 2020-2024, Ankara.

Anonim (2019). Türkiye'deki büyükşehir belediyeleri. 10.06.2021 tarihinde https://www.uzaq.org/turkiyedeki-buyuksehir-belediyeleri_1045.htm adresinden erişildi.

Antalya Büyükşehir Belediyesi (2019). 2020-2024 Antalya Büyükşehir Belediyesi Stratejik Plan, Antalya

Arıkboğa, E. (2013). Geçmişten geleceğe büyükşehir belediye modeli. Yerel Politikalar, 3, 48-96. 
Avrupa Konseyi. (1992) Avrupa kentsel şartı. Avrupa Yerel ve Bölgesel Yönetimler Kongresi.

Avrupa Konseyi (2000) Avrupa Peyzaj Sözleşmesi, Floransa.

Avrupa Konseyi. (2008) Avrupa Kentsel Şartı-2- Yeni Bir Kentlilik İçin Manifesto, Avrupa Konseyi 15. Genel Oturumu, Karar No;269, Strazburg

Aydın Büyükşehir Belediyesi (2019). Stratejik Plan 2020-2024, Aydın.

Balıkesir Büyükşehir Belediyesi (2019). Stratejik Plan 2020-2024, Balıkesir.

Bursa Büyükşehir Belediyesi (2019). Stratejik Plan 2020-2024, Bursa.

Ceylan, A. (2007). Yaşam kalitesinin arttırılmasında kentsel yeşil alanların önemi ve kentsel dönüşüm ile ilişkilendirilmesi. İstanbul Üniversitesi Fen Bililimleri Enstitüsü .

Colding J (2012) Creating incentives for increased public engagement in ecosystem management through urban commons. Cambridge University Press, Cambridge, p.101-124

Denizli Büyükşehir Belediyesi (2019). 2020-2024 Stratejik Planı, Denizli.

Diyarbakır Büyükşehir Belediyesi (2019). Stratejik Plan 2020-2024, Diyarbakır.

Erdem, N. ve Coşkun, A. A., 2009. Avrupa peyzaj sözleşmesi hükümlerinin Türk planlama mevzuatına uyumluluk analizi. İstanbul Üniversitesi Orman Fakültesi Dergisi, 59(2), 67-81.

Erdönmez İ.M. (2004)Ulusal Peyzaj Politikasına Doğru Bir Adım: Avrupa Peyzaj Sözleşmesi,TMMOB Peyzaj Mimarlığı Dergisi, s.92-94,

Erzurum Büyükşehir Belediyesi (2019). Stratejik Plan 2020-2024, Erzurum.

Eskişehir Büyükşehir Belediyesi (2019). Eskişehir Büyükşehir Belediyesi Stratejik Plan 2020-2024, Eskişehir.

Gaziantep Büyükşehir Belediyesi (2019). 2020-2024 Stratejik Plan, Gaziantep.

Gül, A. ve Küçük, V., (2001). Kentsel açık-yesil alanlar ve Isparta kenti örneğinde irdelenmesi. Süleyman Demirel Üniversitesi Orman Fakültesi Dergisi, 3, 27- 48 .

Hatay Büyükşehir Belediyesi (2019). 2020-2024 Stratejik Planı, Hatay.

İstanbul Büyükşehir Belediyesi (2019). Stratejik Plan 2020-2024, İstanbul.

İzmir Büyükşehir Belediyesi (2019). Stratejik Plan 2020-2024, İzmir.

Kalkınma Bakanlığı (2013). Onuncu Kalkınma Planı 2014-2018, Ankara.

Kahramanmaraş Büyükşehir Belediyesi (2019). 2020-2024 Stratejik Planı, Kahramanmaraş.

Kaska, E. Y.(2012). Avrupa peyzaj sözleşmesi (APS) ve Türkiye'deki uygulamaların irdelenmesi .(Doktora tezi). Ankara Üniversitesi Fen Bilimleri Enstitüsü Peyzaj Mimarlığı Anabilim Dalı. 
Kayseri Büyükşehir Belediyesi (2019). Stratejik Plan 2020-2024, Kayseri.

Kıral, B. (2020). Nitel bir veri analizi yöntemi olarak doküman analizi. Siirt Üniversitesi Sosyal Bilimler Enstitüsü Dergisi, 8(15), 170-189.

Kocaeli Büyükşehir Belediyesi (2019). 2020-2024 Stratejik Planı, Kocaeli.

Konya Büyükşehir Belediyesi (2019). 2020-2024 Stratejik Planı, Konya.

Malatya Büyükşehir Belediyesi (2019). Stratejik Plan 2020-2024, Malatya.

Manavoğlu, E. ve Ortaçeşme, V. (2013). Antalya kenti yeşil alanlarının çok ölçütlü analizi ve planlama stratejilerinin geliştirilmesi. Akdeniz Üniversitesi Ziraat Fakültesi Dergisi, 28(1), 11-19.

Manisa Büyükşehir Belediyesi (2019). 2020-2024 Stratejik Planı, Manisa.

Mardin Büyükşehir Belediyesi (2019). 2020-2024 Stratejik Planı, Mardin.

Mersin Büyükşehir Belediyesi (2019). 2020-2024 Dönemi Stratejik Planı, Mersin.

Muğla Büyükşehir Belediyesi (2019). 2020-2024 Stratejik Plan, Muğla.

Ordu Büyükşehir Belediyesi (2019). 2020-2024 Stratejik Planı, Ordu.

Önder, S. ve Polat, A. T. (2012). Kentsel açık-yeşil alanların kent yaşamındaki yeri ve önemi. Kentsel Peyzaj Alanlarının Oluşumu ve Bakım Esasları Semineri, 19, 73-96.

Öztürk, B. (2004). Kentsel açık ve yeşil alan sistemi oluşturulması: Kayseri kenti örneği. (Doktora Tezi). Ankara Üniversitesi Fen Bilimleri Enstitüsü, Ankara.

Sakarya Büyükşehir Belediyesi (2019). 2020-2024 Stratejik Planı, Sakarya. Samsun Büyükşehir Belediyesi (2019). 2020-2024 Stratejik Planı, Samsun. Şanlıurfa Büyükşehir Belediyesi (2019). 2020-2024 Şanlıurfa Büyükşehir Belediyesi Stratejik Planı, Şanlıurfa.

T.C. Cumhurbaşkanlığı Strateji ve Bütçe Başkanlığı (2019), 11. Kalkınma Planı, Ankara.

T.C. Çevre ve Şehircilik Bakanlığı, (2009) KENTGES Bütünleşik Kentsel Gelişme Stratejisi ve Eylem Planı 2010-2023, Ankara

T.C. Çevre ve Şehircilik Bakanlığı, (2012) Türkiye Cumhuriyeti İklim Değişikliği Eylem Planı 2011-2023

T.C. Çevre ve Şehircilik Bakanlığı (2016), Kentsel Tasarım Rehberleri, İstanbul Tekirdağ Büyükşehir Belediyesi (2019). 2020-2024 Stratejik Planı, Tekirdağ.

Tonyaloğlu, E. E. ve Atak, B. K. (2020). Kentsel ekosistem servislerinin haritalanması ve analizi: Aydın ili Efeler ilçesi Örneği. Akademik Ziraat Dergisi, 9(1), 71-80.

Trabzon Büyükşehir Belediyesi (2019). Stratejik Plan 2020-2024, Trabzon. 
Tuğaç, Ç. (2020) Avrupa Kentsel Şartı'ndan Avrupa Yeşil Sözleşmesi'ne: Avrupa'da kentsel politikaların gelişim süreci ve geleceği. Ankara Avrupa Çalışmaları Dergisi, 19(1), 225-267.

Tunçer, P. (2015). Türkiyede kentleşme politikaları. The Journal of Academic Social Science Studies International Journal of Social Science, 37 , 275- 290

Van Büyükşehir Belediyesi (2019). 2020-2024 Stratejik Planı,Van.

Wang, Y., Bakker, F., De Groot, R. and Wörtche, H. (2014). Effect of ecosystem services provided by urban green infrastructure on indoor environment: A literature review. Building and environment, 77, 88-100.

\section{Kaynakça Bilgisi / Citation Information}

Hassamancıoğlu, V. M. (2021). Türkiye'de yerel yönetimlerin kentsel açıyeşil alan yönetimi stratejilerinin değerlendirilmesi. OPUS-Uluslararası Toplum Araştırmaları Dergisi, 18(39), 627-656. DOI: 10.26466/opus.906382. 